\title{
Study on Generation and Composition of Solid Waste Produced in UNIMAS Cafeterias
}

\author{
Syed AlMunir M.Zarak ${ }^{1}$ and Adam, J. H. ${ }^{2}$
}

\begin{abstract}
UNIMAS`s cafeterias generate solid waste everyday and there are 11 cafeterias operating in UNIMAS. The study involved two main cafeterias which are located at Bunga Raya and Alamanda colleges. The objective of the study was to determine the waste generation and composition of solid waste generated by the cafeterias. The study was done by collecting data from both cafeterias on Monday, Wednesday and Friday. The collected waste were weight, mixed, quartered and the composition of the samples were then determined. The amount of waste generated daily in Bunga Raya cafeteria was more compared to that generated in Alamanda cafeteria. Food scraps were the highest component in the solid waste for both cafeterias, followed by plastics, papers, and non-ferrous metal. The energy that can be generated from waste from the whole cafeterias in UNIMAS was estimated at $95,444.33 \mathrm{~kJ} / \mathrm{kg} / \mathrm{day}$. According to the study, the solid waste management can be more efficient by minimizing the food preparation by the cafeteria operators. Besides that, the study can create awareness among students regarding the potential energy that can be harvested from the solid waste.
\end{abstract}

Keywords: Solid waste, Waste generation, Waste composition, energy.

\section{INTRODUCTION}

$\mathrm{M}$

alaysia is experiencing rapid economic growth and urban transformation over the last decade. The amount and types of solid waste have increased corresponding to the economic growth and improving living standard. According to [1], each Malaysian generates an average of $1.7 \mathrm{~kg}$ of solid waste daily, especially in major cities. If the solid waste were collected every day, it is estimated to be more than 15000 tonnes, which is the same height of 4 times Kuala Lumpur Tower. Solid waste has been managed traditionally over 30 years by burying it in landfills with no special intention to study the adverse effect and the potential energy of solid waste. In the year of 2007, the Government of Malaysia gazetted a comprehensive solid waste management and public cleansing act. Federal department which is Environment and public health organization together with non-governmental organizations (NGO`s) have been working together to tackle the solid waste problem. [2]

Universiti Malaysia Sarawak (UNIMAS) is situated at Latitude, $1^{\circ} 55^{\prime} 00^{\prime \prime}$ North and Longitude, $110^{\circ} 33^{\prime} 33^{\prime \prime}$ East. The total student population is 5,976 and total number of staff working in UNIMAS is 1,456 in year 2007.
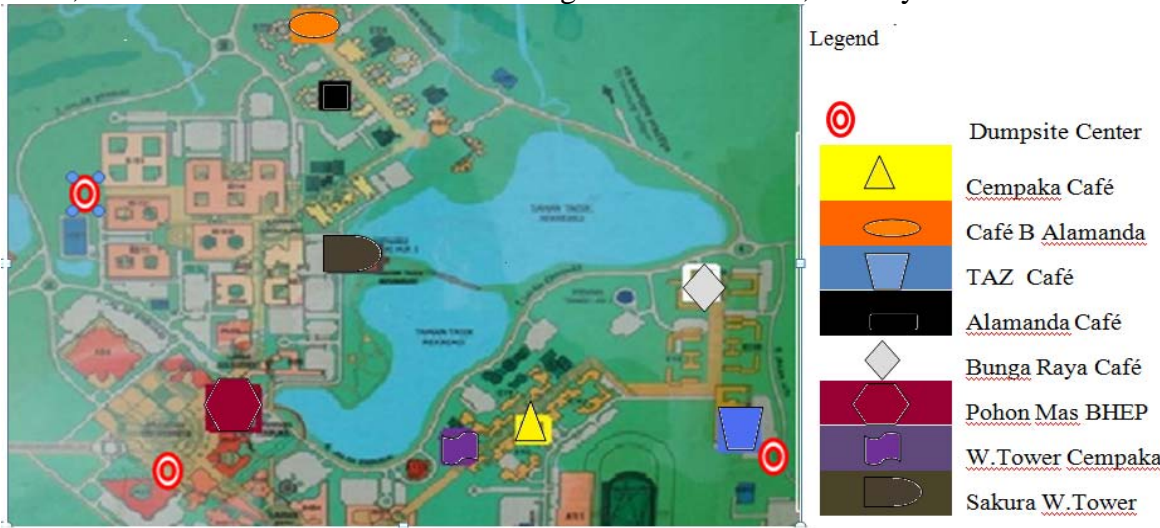

Figure 1: Location of cafeteria within UNIMAS new campus

\footnotetext{
${ }^{1}$ Student, Department of Civil Engineering, Faculty of Engineering, Universiti Malaysia Sarawak, Sarawak, Malaysia,

${ }^{2}$ Lecturer, Department of Civil Engineering, Faculty of Engineering, Universiti Malaysia Sarawak, Sarawak, Malaysia , hajethro@feng.unimas.my
} 
The study area for this cased study is cafeterias in UNIMAS. There are 11 cafeterias in UNIMAS; this include 8 cafeterias in the new campus in the figure 1, and 3 in the east campus which are Seroja cafeteria, Keranji Food Court and Kenanga cafeteria. Two cafeterias are chosen for the detailed study namely Bunga Raya cafeteria and Pohon Mas cafeteria.

More than 20 years ago, the waste management program at the higher educational institutions in industrialized countries had begun [3]. The most established waste management at the institutional level is recycling. According to [4], in USA, 80\% of the colleges and universities have their own institutionalized waste programs which is recycling. These programs are base on characterization study. Brown University has had the recycling programs since 1972 and $45 \%$ of the waste that is generated in the institution were recyclable. Some of the universities even bring their food waste to the local farmers who use it to feed goat and hogs, as part of their waste management practice [5].[6] reported that there is $71 \%$ of the waste recovery potential at the institutions of higher education in Tanzania.

\section{LITERITURE REVIEW}

Solid waste generation in Malaysia depends on its economic status and the lifestyle of the people. There are many literatures showing the factors that are affecting the amount of solid waste generation. According to [7] solid waste generation is depending on the economic status of the area. Besides, [8] reported that the population growth in the capital is affecting the amount of waste generated in Kuala Lumpur. The study also showed that residents in big cities such as Kuala Lumpur and Petaling Jaya generate more solid waste than the people in smaller cities/towns. Other literatures show that, the lifestyle of a certain area can make a great impact on the solid waste generation. According to [9], the lifestyle of the population of a certain area associated with high income can influence the consumption rates and pattern. Besides that, the number of people resides in household also relate to the generation per capita of solid waste as the higher number of people in a household results in less per capita solid waste. Apart from the above, the climate and season affect the amount of solid material produced as waste products of preparing fresh food in the season or climate [10]. For a solid waste composition study, [11] and [12] reported that solid waste composition is mainly dependent on the physical characteristics. Previous literature [8] shows that, for high income area the percentage of plastic was $23.56 \%$, rubber was $9.37 \%$, metal was $5.93 \%$, glass and ceramic $4.03 \%$, textile $3.97 \%$ and organic waste $48.32 \%$. From the study that is conducted by [12], in Kuala Lumpur and the truck load method that is recommended by [13] was used, the composition of food waste is higher at residential area compared to the previous publication by World Bank [14].

\section{METHODOLOGY AND MATERIAL}

The study on solid waste generation and composition in UNIMAS cafeterias involved three main stages :(i) sampling and characteristic, (ii) sample estimating (waste generation, waste composition and energy generated) and (iii) data recording. The sampling and characterization of the solid waste were taken from three different point of generation out of 11 cafeterias in UNIMAS. The samples were taken from Bunga Raya cafeteria, Alamanda cafeteria and Water Tower cafeteria. This three cafeterias were chosen because of their strategic locations and popularity among the students and staff in the campus. The sampling method for this study is spot sampling recommended by [15]. This methodology proposed that all the bags of waste should be open and the content should be mix together to homogenize it. A quarter of the mixed waste is taken to be studied. The samples for this study were taken for 11 consecutive days excluding Tuesday, Thursday, Saturday and Sunday from $9 / 2 / 2009$ to $4 / 3 / 2009$. The estimation for the whole cafeterias was made from the data that were obtained from the three cafeterias that is used for the case study. These include the total solid waste generation, composition and energy. The estimation has to be made because there is no specific data on solid waste generated from the cafeterias and within the campus. Data recording was taken by recording the weight of the categories in the table that was modified from [16].

\section{RESULTS}

Solid waste produced at the cafeterias was collected and disposal after business hours which was about 10 p.m. The waste was transferred by the cafeteria workers to the selected storage facilities which can be found around UNIMAS. It was then collected by Trinekens' truck every Thursday and Tuesday to the landfill site at Mambong. 
Total Estimation of Solid Waste Generation

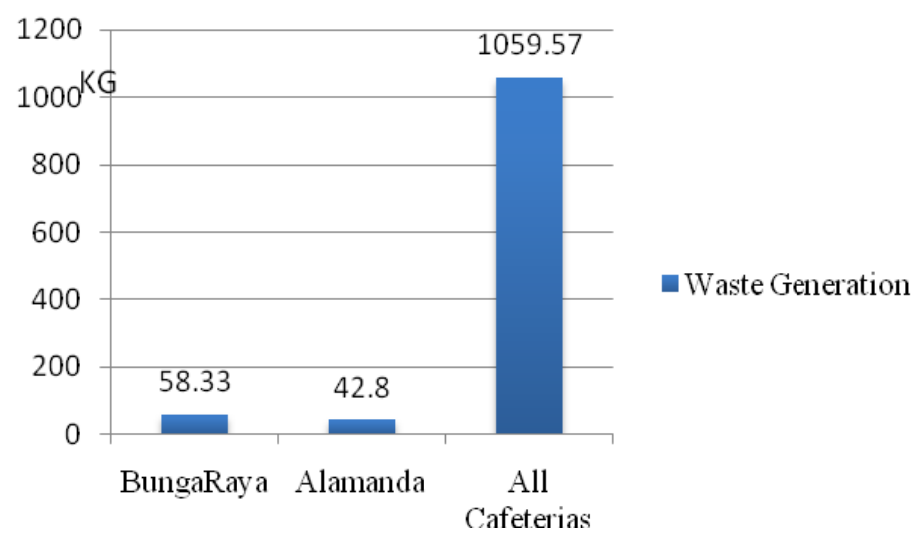

Figure 2 shows the data on waste generated in Bunga Raya and Alamanda cafeterias. From the study conducted, the amount of waste produced daily by both cafeterias is not vastly different from each other. However, Bunga Raya cafeteria produced more waste due to its popularity among the students. The figure also shows the estimation of total waste produced for the whole cafeterias in UNIMAS. The total estimation of the solid waste generation is $1059.57 \mathrm{~kg} / \mathrm{day}$.

Figure 2 Total Estimation of Solid Waste Generation

Table 1 shows the total estimation of waste for the whole cafeteria in UNIMAS. The total estimation of the solid waste generation is $1059.57 \mathrm{~kg}$. The total generation per day for Alamanda cafeteria, Bunga Raya cafeteria, Alamanda B cafeteria, Tun Ahmad Zaidi cafeteria, Pohon Mas (BHEP) cafeteria, Kenanga cafeteria and Seroja cafeteria per day is $50.56 \mathrm{~kg}$.

Table 1 Estimation the Generation of Solid Waste for the Whole Cafeteria in Unimas

\begin{tabular}{|l|l|}
\hline Cafeteria & Total generation \\
\hline Cafe alamanda B & $50.56 \mathrm{~kg}$ \\
\hline Cafe tun ahmad zaidi & $50.56 \mathrm{~kg}$ \\
\hline Cafe cempaka -4 (hostel) & $108.56 \mathrm{~kg}$ \\
\hline Cafe cempaka -10 (river) & $271.4 \mathrm{~kg}$ \\
\hline Pohon mas (BHEP) & $50.56 \mathrm{~kg}$ \\
\hline Water tower sakura - 10 & $271.4 \mathrm{~kg}$ \\
\hline Kenanga & $50.56 \mathrm{~kg}$ \\
\hline Keranji food court - 2 & $54.28 \mathrm{~kg}$ \\
\hline Seroja & $50.56 \mathrm{~kg}$ \\
\hline Alamanda cafeteria & $50.56 \mathrm{~kg}$ \\
\hline Bunga Raya cafeteria & $50.56 \mathrm{~kg}$ \\
\hline Total generation & $\mathbf{1 0 5 9 . 5 7 \mathbf { k g }}$ \\
\hline
\end{tabular}

The value of $50.56 \mathrm{~kg}$ is taken from the average between Bunga Raya cafeteria and Alamanda cafeteria. The generation of the solid waste is averagely generate $27.14 \mathrm{~kg}$ per/day for cafeteria that has two or more owner. The highest waste generation is in the two water tower cafeteria from Cempaka and Sakura, they both generated $271.4 \mathrm{~kg} / \mathrm{day}$ 
Alamanda Cafeteria

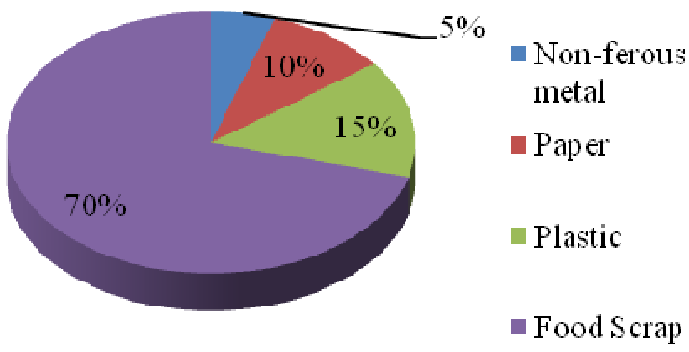

(a)

Figure 3.a illustrates the average composition of solid waste generated in Alamanda cafeteria percent by weight. The highest component of waste produce in the pie chart was food scrap which was $70 \%$. The second highest component of waste produced in the Alamanda cafeteria was plastic (15\%). Paper and plastic were the smallest component waste collected. They were $10 \%$ and $5 \%$ respectively.

\section{Bunga Raya Cafeteria}

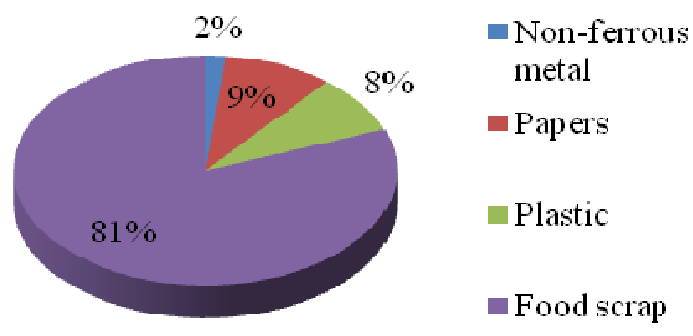

(b)

Figure 3.b shows the average composition of solid waste that was generated in Bunga Raya cafeteria by percent by weight. The highest component of waste was food scrap which was $81 \%$ of produced. The second highest component of waste for Bunga Raya cafeteria was papers with average of $9 \%$. Finally, the wastes from plastic and non-ferrous metal were about $8 \%$ and $2 \%$ of the total respectively.

\section{All Cafeterias}

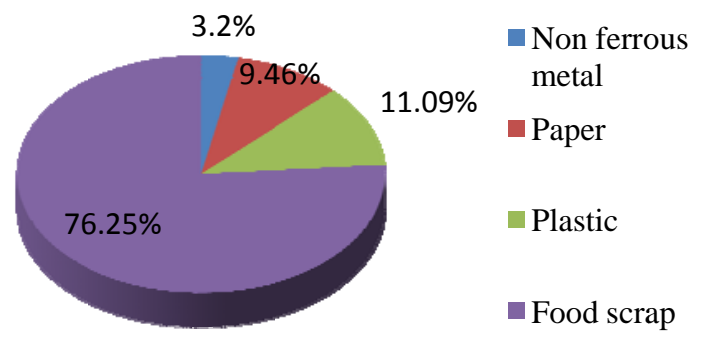

Figure 4: Solid Waste Composition in (a) Alamanda cafeteria,

(b) Bunga Raya cafeteria, (c) all cafeterias

Figure 4 shows the estimation of composition of solid waste in UNIMAS cafeterias percent by weight. It was estimated that the highest component of solid waste in UNIMAS cafeterias was still food scrap, which was 76.25\%. The significant amount of food scrap found in the waste stream of the cafeterias mainly resulted from the food preparation, cooking and cleaning at the cafeteria. This was followed by plastic which was about $11.09 \%$ of solid waste generated in the whole UNIMAS cafeterias. Papers and non ferrous metal both contributed $9.46 \%$ and $3.2 \%$ respectively to the total waste generated. These components existed in the waste stream due to food packaging. 
Table 2 below shows the energy that can be derived from the waste generation of Bunga Raya, Alamanda and all cafeterias. The energy that can be generated by waste from Bunga Raya and Alamanda cafeterias are $2803.91 \mathrm{~kJ} / \mathrm{kg} / \mathrm{day}$ and 2810.46 $\mathrm{kJ} / \mathrm{kg} /$ day respectively. If the waste from all the cafeterias in UNIMAS is to be converted into energy, it is estimated that the amount of energy that can be produced is $95,444.33 \mathrm{~kJ} / \mathrm{kg} /$ day.

Table 2 Energy of Solid Waste in UNIMAS cafeteria.

\begin{tabular}{|c|c|c|c|c|}
\hline \multirow{2}{*}{ Components } & \multirow{2}{*}{$\begin{array}{c}\text { Energy } \\
\text { Btu/lb }\end{array}$} & \multicolumn{3}{|c|}{ Solid Waste (kJ/kg) } \\
\cline { 3 - 5 } & & Bunga Raya & Alamanda & All Cafeterias \\
\hline Organic & & & & \\
\hline$-\quad$ Food waste & 2000.00 & 1316.00 & 956.91 & $38,640.44$ \\
\hline$-\quad$ Papers & 7200.00 & 542.60 & 472.27 & $17,252.96$ \\
\hline$-\quad$ Plastic & 14000.00 & 941.09 & 1370.95 & $39,304.74$ \\
\hline Inorganic & & & & \\
\hline$-\quad$ Tin cans & 300.00 & 4.15 & 444.00 & 246.17 \\
\hline Total in kJ/kg/day & & 2803.91 & 2810.46 & $95,444.33$ \\
\hline
\end{tabular}

\section{DISCUSSION}

In UNIMAS, the volume of solid waste is increasing year by year. This is because the numbers of student entering the university are increasing which also contribute to the increasing number of solid waste generated in the cafeterias in UNIMAS. Due to the increasing amount of solid waste that is produced within UNIMAS, the cafeteria management should follow the solid waste management hierarchy. The hierarchy starts with reduce, recycling, treatment and lastly landfill. The hierarchy of solid waste management is very important in order to reduce the production of solid waste throughout the campus. Besides that, the solid waste that is originally produced at the cafeteria is largely contains organic matters and biodegradable material. If all the organic matters can be recycled, there is no need to send to the landfill and the lifespan of the landfill could be lengthened. Apart from that, to acknowledge UNIMAS occupant the important of saving and what is their responsibility in order to save the environment at the universities level. Lastly, to find and explored the usage of solid waste as the new potential energy.

\section{CONCLUSION}

From the result, a conclusion can be made that the amount of food scrap is the highest. A comparison of the waste from different source which is from Bunga Raya cafeteria and Alamanda cafeteria indicate the variation of data during the sampling. To make the data more reliable, estimation were made throughout the whole cafeteria in UNIMAS to get the amount of solid waste that is generated per day. Besides that, the sampling at the source give a good understanding of waste that is generated and the entire solid waste component that actually generated by the cafeterias. Finally, estimating the amount of energy, it could be said that, the solid waste that is generated at the cafeteria does give high return on energy and it is a waste if the energy is wasted. The estimation of UNIMAS cafeteria energy is $95,444.33 \mathrm{~kJ} / \mathrm{kg}$ per day. Hence, there is a need to explore the technology such as mini electric plan and material recovery facility (MRF) in order to make used of the wasted energy. The mini electric plant could be develop within UNIMAS where all the waste that is generated not only cafeteria can be process to generate steam which then turn to power turbine engine that generates electricity within UNIMAS. MRF is used to provide facilities that capable of processing waste for sorting, cleaning, bulking and later use as raw material for remanufacturing and reprocessing. This actually is a treatment plant where the waste are process to be turn in something new or the waste can be compost through the biological process that is provided within the MRF facility. 


\section{REFERENCES}

[1] IMPAK. (2006). Waste management: Issue 2. Department of Environmental. Malaysia.

[2] Ms. Janet J Balong. (2008). Trienekens and UNIMAS Combines Expertise to Carry Out Solid Waste Study. www.trienekens.com. (12 ${ }^{\text {th }}$ August 2008).

[3] Armijo, C., Ojeda-Benítez, S., Ramírez-Barreto, E., (2003). Mexican educational Institutions and waste management programmes: A University case study. Resources, Conservation and Recycling 39, 283-296

[4] Allen, A.S., 1999. Institutional environmental change at Tulane University. Tulane University, New Orleans, USA.

[5] UF ( University of Florida) Sustainable Task Force, (2002), Final report UF Office of Sustainability, USA. (www.sustainable.UFL.edu)

[6] Mbuligwe, S.E., (2002). Institutional solid waste management practices in developing countries: a case study of three academia institutions in Tanzania. Resources, Conservation and Recycling 35 (3), 131-146.

[7] Hassan, M. N., M. K. Yusoff, W. N. Sulaiman \& R. Abdul Rahman. (1998b). Issues and problems of solid waste management in Malaysia. In: National Review on Hassan, Environmental Quality Management in Malaysia: Towards the Next Two Decades, eds. M.N. Hassan L.A. Abdullah and I. Komo, p: 179-225. Bangi, Malaysia: Institute for Environment and Development (LESTARI), Universiti Kebangsaan Malaysia.

Sivapalan k., Muhd.Noor M.Y., Abd Halim S., Kamaruzzamman S, \& Rakmi A.R (2002). Comprehensive characteristic of the municipal solid waste generated in kuala Lumpur. Regional Symposium on Enviroment and Natural Resources, 1: 359-368.

Fehr, M., de Castro, M.S.M.V., Calcado, M.d.R., (2000). A practical solution to the problem of household waste management in Brazil. Resources, Conservation and Recycling 30 (3), 245-257.

[10] World Bank. (1993). Malaysia - Managing Costs of Urban Pollution. Report 11764-MA. Washington DC: World Bank

[11] Ghazali, A.W., M.N. Hassan Muda, A.(1997), Domestic and Commercial Waste : present and Future trends in state the Environment in Malaysia, eds. BG Ong, p. 382-399. Penang, Malaysia. Consumer Association of Penang.

[12] M. N. Hassan (2001). Solid Waste Management in Southeast Asian Countries with Special Attention to Malaysia. Universiti Putra Malaysia.

[13] Corbit, R.A. (ed). (1998). Standard Handbook of Environmental Engineering. New York: McGraw-Hill

[14] Hoornweg, D. and Thomas, L. (1999). What a Waste: Solid Waste Management in Asia. Working Paper Series for East Asia \& Pacific Region. The World Bank (Urban.Development Division), Washington DC

SECOFI, (1985). Official Maxican Standard approved by the Committee of Environmental Protection, Maxico.

[16] CURC, College and University Recycling Council, (2001). http://www.nrcrecycle.org/councils/CURC/default.htm. (13 ${ }^{\text {th }}$ August 2008). 